\title{
资本驱动下乡村复兴的反思与模式建构 基于济南市唐王镇两个典型村庄的比较
}

\author{
Reflection and Mode Construction of Capital-driven Rural Renaissance: \\ Comparative Study of Two Typical Villages in Tangwang, Jinan
}

摘要: 针对乡村面临的发展困境, 政府与学术界都提出了通过资本下乡来 解决乡村经济、就业等一系列难题, 从而促进乡村复兴。然而, 由于资本 吞没小农等现象频发, 资本以市场化运作带来农业价值进一步提升的同时, 也在一定程度上导致了新的圈地运动。笔者对济南市唐王镇的西王村与大 徐家村两个典型村庄在不同资本驱动下的发展进行实证研究, 探讨了两种 模式对乡村产业、农民权益以及乡村治理等多方面的影响。通过对这两个 乡村发展的比较研究与反思, 借鉴日本乡村复兴经验, 构建了基于乡村复 兴内涵的资本驱动模式。笔者认为, 在资本驱动的乡村复兴过程中, 既需 要自上而下的资本投入与监管机制的建立, 同时需要自下而上的乡村自主 发展与治理体系的完善。既要重视资本驱动乡村发展的工具理性更要重视 乡村自主性的价值理性。

Abstract: Due to rural development dilemma, government and academia find it necessary to solve rural economy, employment and a series of problems through capital investment to promote rural renaissance. However, since it is a frequent phenomenon that capital encroaches smallholder, while capital bring market operation to further enhance agricultural value, it is also leading to a new enclosure movement to some extent. The paper discusses the impact on rural industries, farmers' rights and rural governance of two capital-driven modes through an empirical study on two typical villages. By comparison and reflection of the two rural development condition, the paper constructs the mode of capitaldriven rural renaissance. During the process of capital-driven development, not only the top-down capital investment and regulatory mechanisms are required, but also the bottom-up rural self-development and governance system should be improved. Not only the instrumental rationality of capital-driven development should be paid attention to, but also the value rationality of rural autonomy should be emphasized.

关键词: 资本驱动; 乡村复兴; 模式; 监管机制 ; 乡村治理; 济南市唐王镇 Keywords: Capital-driven; Rural Renaissance; Mode; Regulatory Mechanism; Rural Governance; Tangwang Town of Jinan City

国家自然科学基金 (51578276)

作者: 王京海, 南京大学建筑与城市规划学院, 硕士研究生。wjh9134@163.com 张京祥, 博士, 南京大学建筑与城市规划学院, 教授、博士生导师。 3593786@163.com

\section{引言}

改革开放 30 多年来, 在中国经历了快速的城镇化与 工业化后, 经历了较长时间以乡村衰败为代价的激进现代 化进程后 ${ }^{[1]}$, 越来越多的乡村面临着农民收人低、要素外 流与土地撂荒、空心化与农村治理结构瓦解等一系列发展 困境。乡村长久以来的小农经营模式, 使作为经济增长重 要要素之一的资本严重匮乏 ${ }^{[2]}$, 从而致使乡村无力发展规 模化、现代化农业, 无力保障农民就业, 无力改善乡村基 础设施与居住生活条件等问题。由此, 社会各界希望通过 资本驱动乡村产业振兴、乡村空间建设来扭转乡村长期的

“弱势者” 地位, 带来乡村复兴。希望通过资本下乡把城 镇工商业积累的庞大科技、人力、物力、财力等资源吸引 到农村去, 吸引社会资本加速流向农业、农村, 从而解决 乡村经济、就业、农地经营等一系列难题 ${ }^{[3,4]}$ 。然而, 由 于资本的逐利性, 过度追逐剩余价值, 注定使资本与土地 的结合成为一把双刃剑 ${ }^{[5]}$ 。由此, 是否容许资本下乡以及 如何通过资本的驱动带来乡村的复兴已经成为近年来人们 讨论的焦点。笔者从济南市的明星农业镇一一唐王镇选取 了西王村与大徐家村两个典型案例进行比较研究, 分析资 本从投人到再生产的整个过程, 探讨了在不同资本驱动下 两种模式对于农民、农地、农村的深刻影响, 并试图寻求 资本与乡村合作带来乡村复兴而非乡村被吞噬的模式与路 径。

\section{1 对资本下乡的争论 : 乡村复兴的机遇还是挑战?}

城市资本驱动乡村发展也即 “资本下乡”, 已经成 为政界、学界乃至工商界近年来重点关注的话题。早在 2008 年十七届三中全会, 国家就提出了鼓励龙头企业资 本与农民建立紧密型利益联结机制。2013 年中央一号文 
件明确提出鼓励和引导城市工商资本到农村发展适合企业化 经营的种养业, 在之后历年的中央一号文件以及十八届三中 全会报告中都在提出鼓励工商资本下乡, 完善、规范资本向 农业输人现代生产要素和经营机制（表 1)。在国家鼓励下, 资本下乡来驱动乡村发展成为了国家试图统筹城乡, 反哺农 业的重要抓手, 也成为了乡村吸引城市资本、分享城市红利 从而带来乡村复兴的重要机遇。尤其是中共中央通过《关于 引导农村土地经营权有序流转发展农业适度规模经营的意 见》提出农村集体土地所有权、承包权、经营权 “三权分置” 以来, 为资本介人乡村提供了政策鼓励以及更为便捷的路径, 截至 2014 年 6 月份, 全国土地流转面积达 3.8 亿亩, 其中 流人工商企业的为 3864.7 万亩, 占十分之一。

面对如火如茶的资本下乡, 虽然部分学者从经济发展 的规律出发, 认为资本可以也必然和农民结合实现双赢 ${ }^{[6-8]}$, 城市资本驱动发展可以拉近乡村与市场的距离, 资本市场化 的运作取代村社的自主运营, 可以带来农业价值的进一步提 升, 但是更多学者提出了在缺乏完备的资本引导与监管机制 下, 城市资本驱动既是乡村复兴的机遇更是对乡村发展的挑 战。资本在带动乡村发展的同时, 也是一个资本家剥削小农 的过程, 不可控的“资本下乡” 往往带来资本吞没小农、小 农排斥资本等现象 ${ }^{[9]}$ 。资本如果不断扩大, 将会使农民失去 他们的土地和他们的传统生产方式, 取而代之的是吞掉小农 的大规模资本运作 ${ }^{[10]}$ 。城市资本所代表的激进的现代性模式 消解了乡村社区集体原本式微的庇护作用和土地的传统保障 作用, 往往使农民成为无处落根的边缘人, 并带来村社利益 格局的剧烈变动 ${ }^{[1]}$, 既对乡村治理造成危害, 同时由于资本 的非农化倾向, 也会影响到国家的粮食安全 ${ }^{[12]}$ 。归结起来, 资本驱动会变成资本 “人侵”, 成为新一轮圈地运动。

资本下乡已经在不同发展条件的乡村形成了不同的发展 模式, 无论是工商资本在乡村的独立运营, 还是与农户、合

\section{表 1 国家政策对于资本下乡的鼓励支持}

\begin{tabular}{|c|c|c|}
\hline 时间 & 会议或文件 & 内容 \\
\hline 2008 & $\begin{array}{l}\text { 十七届三中 } \\
\text { 全会 }\end{array}$ & $\begin{array}{l}\text { 推进农业经营体制机制创新, 增加技术、资本等生产要 } \\
\text { 素投人, 鼓励龙头企业与农民建立紧密型利益联结机制 }\end{array}$ \\
\hline 2013 & $\begin{array}{l}\text { 中央一号 } \\
\text { 文件 }\end{array}$ & $\begin{array}{l}\text { 建立严格的工商企业租㐼农户承包耕地准人和监管制度, } \\
\text { 鼓励和引导城市工商资本到农村发展适合企业化经营的 } \\
\text { 种植、养殖业 }\end{array}$ \\
\hline 2013 & $\begin{array}{l}\text { 十八届三中 } \\
\text { 全会 }\end{array}$ & $\begin{array}{l}\text { 鼓励和引导工商资本到农村发展适合企业化经营的现代 } \\
\text { 种养业, 向农业输人现代生产要素和经营模式 }\end{array}$ \\
\hline 2014 & $\begin{array}{l}\text { 中央一号 } \\
\text { 文件 }\end{array}$ & $\begin{array}{l}\text { 探索建立工商企业流转农业用地风险保障金制度, 严禁 } \\
\text { 农用地非农化 }\end{array}$ \\
\hline 2015 & $\begin{array}{l}\text { 中央一号 } \\
\text { 文件 }\end{array}$ & $\begin{array}{l}\text { 鼓励工商资本发展适合企业化经营的现代种养业、农产 } \\
\text { 品加工流通和农业社会化服务; 尽快制定工商资本租赁 } \\
\text { 农地的准人和监管办法, 严禁擅自改变农业用途 }\end{array}$ \\
\hline
\end{tabular}

资料来源：作者根据国家文件整理
作社、公司的合作运营, 都已经在各地得到实践 ${ }^{[13]}$ 。为了深 刻认识资本与农民、农地、农村的互动关系, 本次研究深人 乡村, 根据资本来源与运营主体的不同, 笔者将资本驱动分 为以外部资本自上而下投资运营模式以及以村集体资本自下 而上的投资运营模式，并分别选取了唐王镇大徐家村和西王 村两个典型农业区案例进行比较研究, 试图通过对两种资本 驱动模式下两个村庄农业、农村、农民互动关系的实证演绎 管窥资本与乡村结合之路。

\section{2 实证研究区域与研究方法}

\section{1 研究区概况}

唐王镇隶属于山东省济南市历城区, 位于济南市的东郊, 是济南市著名的特色农业、高新农业、设施农业明星镇, 有 着较好的农业基底, 是久负盛名的 “大白菜之乡”, 近年提 出了着力打造 “百菜之乡 - 都市田园” 知名品牌的唐王现代 农业示范园。唐王镇共有耕地约 81580 亩, 随着资本介人, 近年来, 唐王镇开始了大规模的土地流转, 截止去年, 已有 27000 亩土地流转, 而仅去年一年便有 8000 亩的土地流转。 靠近乡镇公路两侧的土地更是成为城市资本人驻的据点, 成 立了生态农业、绿色农业试点等一系列公司或者合作社，土 地大规模流转经营已成定势。本次研究的两个村庄分别位于 唐王镇县道孙唐路与乡道唐临路两侧 (图 1), 并分别通过资 本运作建立起初荷生态农业发展公司与宏园翔蔬菜专业合作 社, 两者都已经成为了济南市土地流转、规模经营的典型。

\subsection{1 大徐家村一一外部企业投资建立农业公司}

大徐家村位于济南市唐王镇县道孙唐路的东侧, 土地面

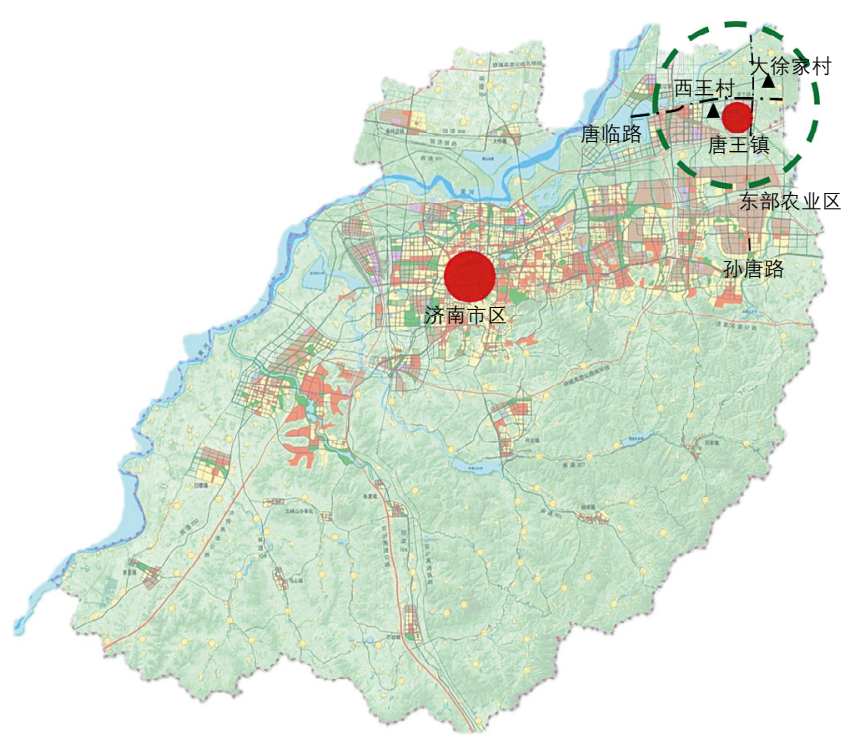

图 1 大徐家村、西王村区位 资料来源 : 作者绘制 
积 3043 亩, 是唐王镇耕地连片面积最大的村庄, 人口 2812 人, 共 716 户, 农业产业主要以种植小麦、玉米、花卉苗木 等为主。近十年来, 大徐家村通过机械零部件、锻压产品加 工等工业产业的发展, 经济水平连年上升, 与城市的交流也 更加活跃，越来越多的农民选择去工厂打工或自己开厂，并 希望将自己的农地流转。同时, 由于大徐家村耕地连片, 交 通便利, 非常适宜规模化经营, 因此, 对城市资本具有极大 的吸引力。

2012 年, 联荷实业集团在唐王镇政府的支持下, 通过与 大徐家村集体协作，投资以 1500 元/亩的高流转价格承包 了大徐家村三分之二的土地, 约 2000 亩来成立初荷生态农 业发展有限公司, 成为唐王现代农业示范园的重点规划园区。 公司通过村集体与农民达成流转土地 15 年的合同, 开始了 对园区的市场化经营。

\subsection{2 西王村一一村集体借贷投资建立自主合作社}

西王村位于唐临路北侧, 土地面积 800 亩, 人口 647 人, 共 270 户, 农业产业主要以种植草莓、小麦玉米与蔬菜为主。 由于西王村村庄面积小, 缺乏经营性村庄建设用地, 因此西 王村一直以来就是一个以农业作为唯一产业的村庄, 农民收 人主要以农业收人以及去镇上打工为主。近年来, 随着公交 的开通, 越来越多的青壮年劳动力选择去城里打工, 随之土 地撂荒的现象开始出现。

2009 年, 村集体响应市政府合作化经营的号召, 在村长 的带领下，通过村民自愿人社的形式来集资流转农民土地， 建立了宏园翔合作社, 发展合作社农业。由于缺乏原始资本, 村长与人社村民通过集体借贷的方式以 1100 元/亩的价格 流转社员以及村内农民的土地 360 亩, 并与农民形成了 8 年 的承包合同，村内大部分撂荒土地都被流转。合作社打破原 来单一的粮食作物经营模式, 开始通过蔬菜大棚等发展多样 化的经济作物。

\section{2 研究方法}

笔者在田野调查中主要采用了参与式观察、半结构访 谈、问卷调查等方法。笔者以公开研究者的身份与唐王镇 农委负责人进行访谈, 形成了对唐王镇土地流转与农业公 司、合作社经营整体上的认识, 并深人西王村宏园翔合作 社及大徐家村初荷生态农业公司, 与社长以及公司相关负 责人进行了访谈, 进行了详实的记录与观察, 形成了对两 种资本驱动模式下乡村发展的感性认识。在此基础上, 针 对核心问题按户随机发放问卷，采用现场督促答疑的方式， 有效问卷率 $100 \%$, 其中大徐家村发放问卷 63 份，西王村发 放问卷 70 份。问卷为文章定量数据的主要来源。笔者通过
对观察和访谈内容的思考以及问卷数据的辅助形成对两个 村庄两种模式的比较研究。

\section{3 两个典型乡村发展模式比较研究}

\section{1 资本运作模式}

大徐家村与西王村在两种不同资本驱动下形成了不同的 资本运作模式。大徐家村的投资主体联荷实业集团, 除了生 态农业投资外, 还下辖地产、商业、物业、金融等产业公司。 集团通过投人大量资金来流转农民土地、进行生态园区的建 设以及园区工作人员的雇佣等组建初荷生态园, 进行特色种 植、生态休闲、生态教育以及特色节庆展示等活动, 并通过 与市场对接, 采用积极营销的方式来获得收益, 而收益一部 分投人生态园的再生产,一部分则投人公司其他产业（图 2)。

与大徐家村外部企业资本投人不同, 西王村宏园翔合作 社的资本则主要依赖于合作社社员的集资与借贷。另外, 由 于村集体合作经济本身高度的政治意义以及济南市对于合作 经济的政策鼓励, 每年园区还可以得到 10 万元政府补贴以 及设施补助。村民自愿加人合作社, 然后通过集体借贷的资 本以及补助投人土地流转、合作社农业设施建设以及人员雇 佣来形成合作社。合作社主要通过规模化特色种植以及绿色 养殖的方式来实现收益。收益的一部分用来农业产业的再生 产, 而剩余收益则成为了合作社社员的分红（图 3)。

\section{2 乡村产业发展}

虽然两村资本运作方式不同, 但是都通过资本的投人完 成了对土地的流转, 并且实现了现代农业设施的建设与完善, 包括灌溉设施、蔬菜大棚等都相应投人了大量的资金。因此 两者也都实现了对农地的规模化、现代化经营, 通过农产品

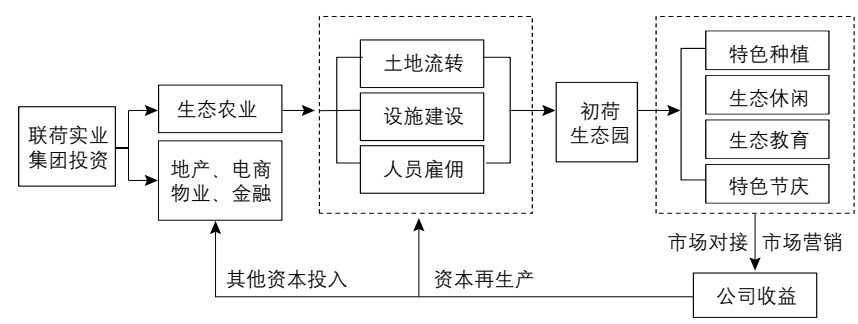

图 2 大徐家村外部资本驱动下的运作模式 图片来源 : 作者绘制

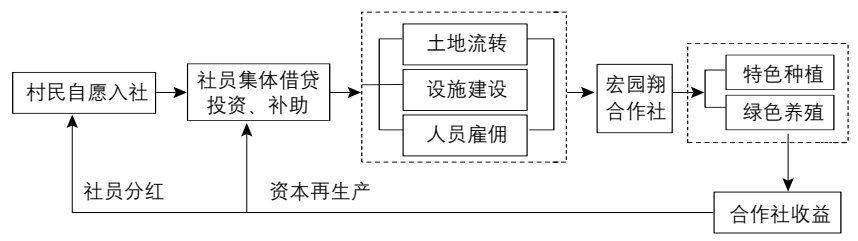

图 3 西王村集体借贷资本驱动下的运作模式 图片来源 : 作者绘制 
多样化、绿色化、精品化的研发与种植来提高附加值, 试图 改变乡村“穷农富工”的寞境。

联荷实业集团投资生态农业, 将流转的土地进行独立开 发与收益, 其强大的资本实力与丰富的市场经验给大徐家村 的乡村产业发展带来了巨大的提升。一方面, 集团投资的初 荷生态园已经形成了完善的园区规划, 包括苗木种植区、蔬 菜种植区、百花园、百果园、艺术粮田区等园区, 并且通过 专业的农业咨询形成了良好的产业发展预判与合理的产业规 划。在强大的资金支持下, 生态园还进行了农家乐、采摘等 生态休闲开发, 并且建立了生态教育基地, 充分利用生态农 业的休闲、教育价值。

另一方面, 公司具有专业的市场运营与管理, 除了种植 之外, 还有配送、研发等一系列部门, 并通过员工技能培训 等提高运营效率。公司通过设立市场部专门进行市场调研、 分析, 农业生产紧跟市场形势, 并且在济南市政府 “菜篮子” 工程扶持下主动与各大超市对接出售, 保障产品的销量与销 路。同时, 公司通过媒体、标志路牌等方式进行营销, 将农 业生态效益进行放大, 主动迎合城市消费需求。现在园区已 经形成了采摘节、荷花节、生态越野等一系列活动, 由于良 好的园区规划以及生态农业的旗帜可以给政府带来更多的绿 色政绩, 因此, 地方电视台对其宣传也为营销助力。据统计, 生态园近三年的盈利分别为 450 万、 345 万、 530 万元, 不断 的资金投人大大促进了农业生态、休闲功能的发育。但是不 可忽视的是, 公司的盈利只有 $40 \%$ 会继续投人农业产业发展, 而 $60 \%$ 的收益则被联荷实业集团用来投资其他产业。

西王村在有限的资本支持下, 合作社依然力图实现精品 化、现代化农业, 而农业产业的选择也是基于合作社与村民 的集体商议。合作社通过蔬菜大棚、绿色养殖等方式实现了 连续三年的盈利, 社员也得到了连续三年的分红。然而, 合 作社三年利润额分别为 30 万、 21 万、 23 万, 利润的减少也 反映了合作社运营的问题。

首先, 产业发展的盲目性以及对市场缺乏敏感性。因乡 村规划、农业规划的缺乏, 没有像初荷生态园类似的市场指 引, 产业发展经常会发生同质竞争的现象, 而且由于缺乏 市场对接, 经常会出现农产品过饱或过缺的现象。西王村 曾经希望利用生态、绿色优势发展采摘与农家乐, 但直于 区位与营销不力, 来园游客胗胗无几, 运行了半年的农家 乐餐厅在经济压力下倒闭。其次, 合作社依然面临着乡村 熟人社会的管理问题, 用工管理难, 缺乏市场化的运营组织。 合作社雇佣农民作为员工, 素质参差不齐, 影响了运营效率。 最后, 在产业发展中合作社面临的严重问题还是资本的缺 乏, 资本仅是人社村民通过贷款集资以及政府少量补贴而 来, 但农业的长周期的效益回报以及贷款的高利息使合作
社经常面临资金不畅的问题。与外部城市雄厚的资本相比, 合作社的借贷资本的周转能力、抵御风险能力都为合作社 的发展提出了难题。

\section{3 农民就业收入与土地权益}

通过土地流转, 无论是大徐家村的 1500 元/亩还是西 王村的 1100 元/亩的价格, 在大大解放乡村劳动力的同时, 也带给了农民更高更稳定的土地收人。在大徐家村, 初荷生 态园通过农业生产所得利润被联荷实业集团全部获取，然后 进行资本再生产，用于除了农业投资之外的相应商业、地产、 物流等其他产业投资。因此, 农民在流转期限内难从土地中 获取收益。除了土地流转资金, 农民也难以分享到资本运作 带来的红利。此外, 在农民就业上, 由于初荷生态园的市场 化、效率化经营模式, 所雇佣员工多是经过专业培训的农业 工作者, 而文化水平较低的农民难以在生态园取得就业机会。 在问卷调研中, 本村只有 $15 \%$ 的农民在生态园工作, 平均 年龄 42 岁（表 2), 50 岁以上的农民几乎难以得到就业机会, 而大部分村内青壮年农民仍是以外出打工为主。

相比较于大徐家村的资本驱动模式, 西王村的合作社模 式在保障农民土地流转收人的同时，人社的农民还可以得到 土地收益的分红, 产业若是发展良好, 社员则可以源源不断 地从土地中获取收益。而社员的分红则大多数用于投人合作 社的扩大再生产以及村庄农业基础设施的营建，保障了农业 产业的不断扩大发展。就业方面, 相比较于大徐家村初荷生 态园，合作社的从业农民则 $80 \%$ 来自本村，而就业平均年 龄更是达到 53 岁, 使由于年龄过大或技能缺乏的农民得到 再就业的机会。由此, 合作社既带动乡村产业的发展, 也解 决了大部分乡村农民的就业问题, 在浓厚的“集体主义”氛 围下，合作社与农民的关系愈发紧密。

在农民土地权益的保障方面, 一方面由于西王村是合 作社与村民直接沟通, 保障了农民自愿流转土地, 另一方面 合作社以农业经营为主的理念，保证了农民土地继续投人的 是农业生产。同时, 由于土地权益与社员息息相关, 流转土

\section{表 2 西王村与大徐家村农民就业与收入调查}

\begin{tabular}{|c|c|c|c|c|c|c|c|}
\hline & & \multicolumn{3}{|c|}{ 西王村 (70) } & \multicolumn{3}{|c|}{ 大徐家村 (63) } \\
\hline & $\begin{array}{c}\text { 本村农民就业 } \\
\text { 比例 }\end{array}$ & \multicolumn{3}{|c|}{$80 \%$} & \multicolumn{3}{|c|}{$15 \%$} \\
\hline 就 & 就业平均年龄 & \multicolumn{3}{|c|}{53} & \multicolumn{3}{|c|}{42} \\
\hline $\begin{array}{l}\text { 业 } \\
\text { 收 }\end{array}$ & 就业是否稳定 & $\begin{array}{c}\text { 是 } \\
28.60 \%\end{array}$ & $\begin{array}{c}\text { 否 } \\
50.00 \%\end{array}$ & $\begin{array}{l}\text { 说不清 } \\
21.40 \%\end{array}$ & $\begin{array}{c}\text { 是 } \\
71.40 \%\end{array}$ & $\begin{array}{c}\text { 否 } \\
28.60 \%\end{array}$ & $\begin{array}{l}\text { 说不清 } \\
0.00 \%\end{array}$ \\
\hline 人 & 土地分红 & \multicolumn{3}{|c|}{ 有 } & \multicolumn{3}{|c|}{ 无 } \\
\hline & 土地流转价格 & \multicolumn{3}{|c|}{1100} & \multicolumn{3}{|c|}{1500} \\
\hline
\end{tabular}

资料来源 : 作者根据调查问卷整理 
地的农民也可以在乡村熟人社会的条件下直接与社员对话协 商, 因此也在最大程度上保证了土地在资本运作生产中不会 受到破坏。

然而对于大徐村来说, 土地的流转是公司通过村干部与 农民协商流转的, 农民难以与公司直接对话，因此注定了农 民的弱势地位。在笔者的调研中, 较多农民因为担心公司流 转自己土地时间太长, 担心土地会受到破坏而对于是否流转 产生迟疑, 但是在村干部诱导下最终选择流转, 因此大徐村 的土地流转可以被认为是公司与村干部的一次 “合谋”。资 本在经营土地过程中也确实印证了农民的担忧。在农业园营 建过程中, 除了基本的农业生产, 将土地深挖蓄水建设娱乐 设施, 在农地上建设展示基地等构筑物现象频发（图 4, 图 5), 对此有超过 $20 \%$ 的农民认为自己的土地进行了非农业生产 并且遭到了破坏 (表 3)。可见, 外部资本的逐利性在带来 产业发展的同时也是以牺牲农民、农地利益作为代价的。

\section{4 乡村治理}

中共十八届三中全会提出了 “国家治理体系与治理能力 现代化” 的课题, 乡村治理是国家治理体系中基础的、重要 的环节, 毫无疑问也是最弱的环节之一。多年乡村的衰败致 使乡村治理落后, 逐渐失去了主动发展的能力。国家社会对 乡村治理的重视也是希望通过治理, 借助外部资本来充分激 发乡村自发发展的能力, 从而对乡村生态环境、基础设施、 公共服务等资源进行合理配置和生产, 带来乡村复兴。笔者 在西王村的调研中发现, 虽然通过资本运作的农业产业发展 还未达到理想水平, 但是在问卷中, 有 $71.4 \%$ 的农民认为合 作社在发挥带动农民致富的作用，而村委的话语权也在逐步 扩大。农民对 “集体主义的复兴” 以及合作社未来的发展充 满信心。而合作社利用部分收人重新修缮了村庄祠堂, 并在 村内设置垃圾回收站, 开始整治村庄环境, 在新年开始恢复 村内舞龙舞狮的习俗, 更使得村内人气进一步集聚。

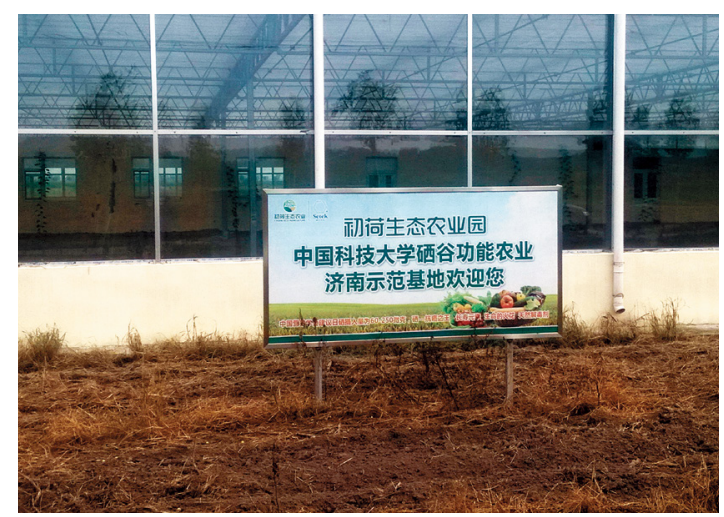

图 4 大徐家村农地上构筑物 图片来源 : 作者拍摄
大徐家村则面临较大的治理困境。在现阶段的城镇化进 程中, 较多农民无法完全城镇化, 乡村仍是重要的基层治理 组织, 而外出打工与土地保障相结合也成为农民重要生存路 径。联荷集团强大的资本则使农民与村集体变得弱势, 15 年 的土地流转以及公司独自经营更是使农地脱离了乡村, 农民 脱离了农地, 也就脱离了乡村。在失去了土地这一乡村的发 展根基之后, 不仅村内空心化、老龄化现象更为严重, 而且 青壮年打工一旦失业, 又失去了土地保障, 则可能带来较多 的社会问题, 致使乡村面临更大的治理难题。大徐家村委在 强大资本面前被架空, 既无法与公司平等对话, 也无法得到 村民的拥护。在问卷调查中, 仅有 $32.8 \%$ 的村民认为村集体 仍可以带领村民致富, 带动乡村复兴。因此, 对比可得, 如 果合理的利用资本, 将资本控制在村社理性的范围内, 将大 大提升乡村治理的可能, 反之, 失去了村社主动权, 被资本 反噬, 乡村治理则无从谈起。

\section{4 反思与建构 : 资本驱动乡村复兴的积极作用模式}

\section{1 基于案例比较研究的反思}

通过上述两个典型案例的比较研究, 可以看到两个村 庄通过资本驱动都带来了农民收人的提升以及农业规模化、 效率化的发展。然而, 乡村复兴的内涵远非乡村产业的发 展, 而是乡村文化、特色、环境、治理能力等全方位的提 升 ${ }^{[14]}$ 。大徐家村的公司模式由于其规范化运营, 市场化营

\section{表 3 西王村与大徐家村土地情况对比}

\begin{tabular}{|c|c|c|c|c|c|c|c|}
\hline & \multicolumn{3}{|c|}{ 西王村（70） } & \multicolumn{3}{|c|}{ 大徐家村（63） } \\
\hline & & 是 & 否 & 说不清 & 是 & 否 & 说不清 \\
\hline \multirow{4}{*}{$\begin{array}{l}\text { 土 } \\
\text { 地 }\end{array}$} & 土地是否自愿流转 & $92.80 \%$ & $0 \%$ & $7.20 \%$ & $63.50 \%$ & $15.80 \%$ & $20.70 \%$ \\
\hline & $\begin{array}{l}\text { 土地是否进行了非农 } \\
\text { 业生产 }\end{array}$ & $8.60 \%$ & $91.40 \%$ & $0.00 \%$ & $21.70 \%$ & $78.30 \%$ & $0 \%$ \\
\hline & 土地是否受到过破坏 & $0 \%$ & $100 \%$ & $0 \%$ & $21.70 \%$ & $78.30 \%$ & $0 \%$ \\
\hline & 土地流转年限 & \multicolumn{3}{|c|}{8 年 } & \multicolumn{3}{|c|}{15 年 } \\
\hline
\end{tabular}

资料来源 : 作者根据调查问卷整理

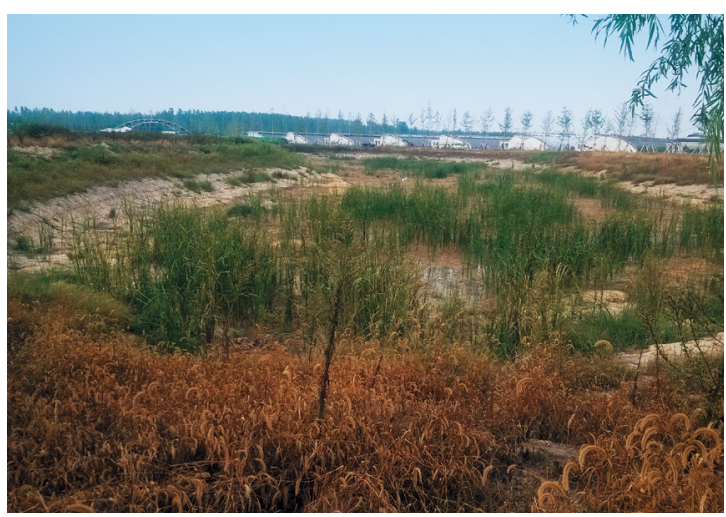

图 5 大徐家村农地深挖的池塘 图片来源 : 作者拍摄 
销, 大大提升了农村农地的生产效率。然而, 外部资本的 逐利性带来资本的 “越位”, 尤其在缺乏监管的情况下给大 徐家村带来了乡村治理的瓦解以及农民权益的丧失等问题。 资本通过独立的流转、经营土地, 切断了农民与土地的联系, 失地农民与村集体更是难以与强大的城市资本平等对话, 农 民在面对失业、土地纠纷等问题时无力抗争, 乡村产业的发 展是以牺牲乡村社会、文化以及农民的长久利益为代价的。 资本驱动下村集体丧失了主动权, 也失去了主动发展的能 力, 成为了某种意义上的城市资本的圈地运动而非真正意 义的乡村复兴。

反观西王村, 村集体借贷投资的自主合作社模式虽然由 于其资本投人小, 且借贷资本也有着一定的风险性, 同时在 产业缺乏市场化分析、营销的情况下, 产业发展缺乏规划, 效率不如市场化经营的公司模式。但是通过合作社的建立, 乡村获得了自主发展的机会, 治理体系也在逐步构建。首先 无论是社员还是普通农民, 都在土地流转中获得比之前更高 的收益, 社员还可以获得土地增殖收益。此外, 合作社还在 一定程度上解决了乡村劳动力的就业问题土地。更为重要的 是, 在资本驱动产业发展的过程中, 合作社始终在发扬村社 理性, 资本的运作始终将农民、农地与乡村联系在一起, 群 策群力, 体现了乡土中国集结众家之力、众家之言以实现村 庄、产业的稳态治理模式 ${ }^{[15]}$ 。既重塑了农村被冲垮的村社结 构等一系列集体性要素, 也在提倡复兴集体主义的背景下有 其政治意义。

\section{2 资本驱动乡村复兴的模式建构}

通过对典型案例的反思总结, 基于乡村复兴的基本内涵, 笔者认为, 在资本驱动乡村复兴的过程中, 既需要自上而下 的资本投人与监管机制的建立, 也需要自下而上的乡村自主
发展与治理体系的完善, 以构建统筹、协调乡村多元发展的 乡村复兴模式（图 6)。

首先, 寻求资本介人乡村后的合理 “位置”。资本介人 乡村, 不应是以外部资本的市场化运营完全取代乡村的自主 发展, 一旦资本完全控制了农村土地以及乡村产业发展, 就 像大徐家村所面临的, 由于资本的逐利性, 资本 “越位” 将演变成资本吞没小农的“圈地运动”, 因此需要给外部资 本在乡村的发展界定合理的位置。正如日本在乡村 “一村一 品” 运动中, 规定外部资本所负责的是为农民提供政策、技 术开发、市场开拓的支持，而农民依旧掌握产业发展的自主 权 ${ }^{[16]}$ 。因此, 外部资本的合理位置应是提供乡村产业发展的 技术、人才、市场化服务, 以及建立利益分享与增长机制, 让农民真正享受资本所带来的产业发展增值。

第二, 建立规范的资本投人与运作监管机制。资本下乡 本身并不可怕, 可怕的是对资本缺乏监管与指导、对农民权 益没有保障的资本下乡。尤其面对资本投入后土地经营非农 化、土地破坏、农民权益受损等现象, 必须强化法律政策监 管力度, 约束资本的 “越位” 行为。1969 年, 日本为了处 理资本下乡侵蚀小农的问题, 颁布了《农业振兴地区整治建 设法》来对资本驱动的农业振兴区进行用地开发管制 ${ }^{[17]}$, 严 禁非农生产与圈地运动。而在中国资本下乡如火如茶的今天, 必须进行规范的资本投人与运作监管机制建设以及基层的监 督平台建设, 以确保农村、农民利益不受侵害。

第三, 通过农业协作组织机构建设来加强农民自主发展 的能力, 维护农民权益, 重塑村社自主性。乡村的复兴, 应 是可以自如地利用外部资本来充分发展自身, 从而实现自主 的、持续的发展。然而, 长久以来的小农社会使农民在面临 资本 “人侵” 时失去了维权的意识与平台, 如大徐家村农民 面临的失地诺境; 长久小农经营使大部分农民无法高效率地

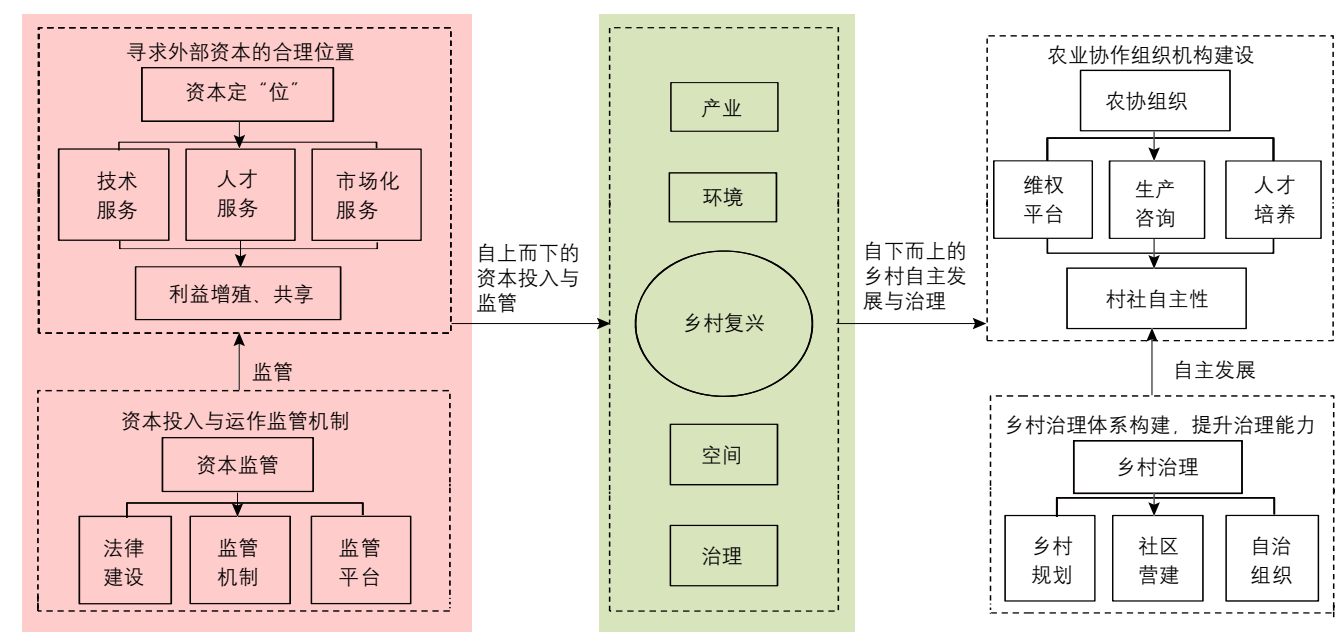

图 6 资本驱动下的乡村复兴模式框架 资料来源 : 作者自绘 
运营外部资本, 就像西王村农民合作社所面临的运营困境。 因此，必须通过农业协作组织等乡村服务组织的建立来提高 农民组织程度与参与程度，为农民提供法律服务、生产咨询 以及人才培养，指导村民合理地运营资本，使乡村能够真正 的自主发展。

最后, 完善乡村治理体系, 提升乡村治理能力。完备的 治理体系可以使乡村更自如地应对资本, 将被动输血转化为 主动造血, 而中国乡村的治理境况与发达国家相比无疑是十 分落后的, 原来村社宗族式的治理瓦解, 以村委为代表的新 的自治主体明显尚未成熟, 尤其在近几年乡村衰落、空心化 的形势下, 治理更是显得力不从心。然而, 在大量资本进人 乡村的状况下, 治理体系的缺乏致使乡村极易受到资本的冲 击, 更为严重的还可能导致乡村被资本吞没。因此, 借鉴发 达国家的乡村建设经验, 通过乡村规划来规范引导产业、空 间发展方向，通过除了行政体制的自治组织构建以及社区营 建的理念来激发村集体的治理能力, 建立乡村治理体系。以 治理促产业, 从而进一步带动乡村特色、文化、环境的可持 续发展以及真正意义上的乡村复兴。

\section{5 结论与讨论}

在新的城镇化阶段下，伴随着都市区化的发展以及城市 消费体系的扩散延伸，中国农业资本化在政府的大力推动下 已成定势。然而, 随着城镇化发展, 部分村庄的收缩甚至消失, 农村人口转为城镇人口的进程必将持续进行。因此, 笔者构 建的乡村复兴模式, 是以乡村发展全局的视角来阐释资本与 乡村之间的互动逻辑关系。西王村与大徐家村的案例诠释了 在资本驱动下, 尤其是市场化、效率化的资本运营毫无疑问 对乡村复兴具有重要意义, 然而如果资本的运作没有被规范, 资本的激进现代性没有被约束，必然会带来小农被吞没以及 乡村治理的瓦解。资本驱动的乡村复兴模式既要符合将资本 合理化、规范化运营以遵循市场的规律的工具理性, 也要坚 守村集体的话语权以及乡村自主发展的价值理性, 从而带来 乡村真正意义上的主动复兴。近年来, 随着互联网 + 等一系 列现代技术的兴起, 乡村与资本的时空距离被大大缩短, 为 乡村提供一个自我营销平台的同时也使乡村面临着更复杂的 资本介人，乡村复兴在面临更多机会的同时，也在遭遇更大 的挑战。因此, 未来也需要更加广泛的田野调查, 更加全面 的制度设计与政策保障来促进资本与乡村更好地结合, 需要 乡村治理能力进一步提高, 治理体系进一步完善, 使乡村在 城乡系统中成为更重要的一环而非消失的一环。UP

\section{参考文献}

[1] 张京祥, 申明锐, 赵晨. 超越线性转型的乡村复兴一一基于南京市高
淳区两个典型村庄的比较 [J]. 经济地理, 2015(03): 1-8.

[2] 叶飞文. 要素投入与中国经济增长 [D]. 厦门大学, 2003.

[3] 程新友. “资本下乡”意味着什么? [J]. 社会观察, 2009(03): 38-39.

[4] 罗亚轩. 工商资本下乡对农村的影响 [J]. 农村经济与科技, 2015(02): 175-176.

[5] 马九杰. “资本下乡”需要政策引导与准入监管 [J]. 中国党政干部论 坛, 2013(03): 31 .

[6] 杨水根. 资本下乡支持农业产业化发展: 模式、路径与机制 [J]. 生态 经济, 2014(11): 89-92.

[7] 高娟.保障农民利益引领资本下乡 []]. 合作经济与科技, 2012(09): 34-35.

[8] 王海娟. 资本下乡的政治逻辑与治理逻辑 [J]. 西南大学学报（社会科 学版) , 2015(04): 47-54.

[9] 全志辉, 温铁军. 资本和部门下乡与小农户经济的组织化道路——兼 对专业合作社道路提出质疑 [J]. 开放时代, 2009(04): 5-26.

[10] 梁韵诗.资本下乡的遭遇 [D]. 华中师范大学, 2014.

[11] 折晓叶. 合作与非对抗性抵制——弱者的 “韧武器” [J]. 社会学研究, 2008(03): 1-28.

[12] 黄宗智. 华北的小农经济与社会变迁 [M]. 中华书局, 2000 .

[13] 王文龙. 范式冲突、农业生产模式转型与资本下乡之争 [J]. 理论导刊, 2013(11): 13-17.

[14] 张京祥, 申明锐, 赵晨.乡村复兴: 生产主义和后生产主义下的中国乡 村转型 [J]. 国际城市规划, 2014(05): 1-7.

[15] 何慧丽, 邱建生, 高俊, 等.政府理性与村社理性：中国的两大“比较 优势”[J]. 国家行政学院学报, 2014(6): 39-44.

[16] 张永强, 郭翔宇, 秦智伟。日本“一村一品”运动及其对我国新农村 建设的启示 [J]. 东北农业大学学报 (社会科学版) 2007(06): 11-14.

[17] 王雷. 日本农村规划的法律制度及启示 [J]. 城市规划, 2009(5): 42-49.

(本文编辑：秦潇雨)

\section{更 正 启 事}

本刊 2016 年第 4 期 “专题研究” 栏目文章《应对人口 减少地区的乡村基础设施建设策略——德国乡村污水治理 经验》一文, 注释内容出现偏差: 第 139 页注释 (1) 内容应 对应第 140 页第一段中的注释 (1), 该页的其他注释号码顺延, 特此更正!

《国际城市规划》编辑部 2016 年 10 月 19 日 